\title{
COMMENTARY
}

\section{Matrix metalloproteinases and the vascular smooth muscle cell migration in hypertension}

\author{
Vanessa de Almeida Belo and Michele M. Castro*
}

\begin{abstract}
Vascular smooth muscle cells (VSMC) migration and proliferation may be the main precursors of the chronic and maladaptive vascular remodeling in hypertension. The proteolysis of extracellular matrix and the phenotype switch of VSMC need to occur in order to allow VSMC migration and the vascular remodeling and hypertrophy. The matrix metalloproteinases (MMPs) are well known to degrade many extracellular matrix and non-extracellular matrix components to favor VSMC migration and their phenotype switch. Targeting MMPs may reduce VSMC migration and the arterial maladaptation caused by hypertension and its cardiovascular events.
\end{abstract}

Keywords: Matrix metalloproteinases, vascular smooth muscle cells, hypertension, MMP, VSMC, hypertrophy

\section{Introduction}

Hypertension is characterized by a sustained elevation of arterial pressure ${ }^{1}$ which causes mechanical stress within the arterial wall and leads to vascular remodeling. ${ }^{2}$ The underlying pathological processes in vascular remodeling are associated with migration and proliferation of vascular smooth muscle cells (VSMC), which are located in the tunica media of arteries. ${ }^{3}$ Persistent and severe stretching of the vessel wall caused by hypertension may also result in VSMC hypertrophy, which preferentially occurs in the large conduit arteries, such as aorta. ${ }^{2,} 4$ Hypertensioninduced hypertrophic remodeling is usually observed as increased arterial wall thickness, cross-sectional area and media to lumen ratio ${ }^{5,6}$ and may be the result of extracellular matrix (ECM) proteolysis and the phenotype switch of contractile to synthetic VSMC. ${ }^{3}$ The matrix metalloproteinases (MMPs), a family of zinc-dependent proteases, have been implicated in the chronic vascular remodeling of hypertension due to their proteolytic effects on ECM and non-ECM components, which may contribute to the capacity of VSMC to migrate and proliferate. ${ }^{7-9}$

\section{Role of MMPs in maladaptive vascular remodeling in hypertension}

Increased activity of MMPs is generally observed in animal models of hypertension and contributes to excessive ECM proteolysis, VSMC reorganization and hypertrophy. ${ }^{10}, 11$ Among many MMPs, the gelatinases (MMP-2 and MMP-9) and MMP-14 were associated with increased arterial media and intima thicknesses of hypertensive animals. ${ }^{10,} 11$ Our group showed that treating two-kidney one-clip
(2K-1C) hypertensive rats with doxycycline, an MMP inhibitor, inhibited MMP-2-induced chronic maladaptive vascular remodeling by reducing the deposition of elastin and collagen in aortas and the VSMC hyperplasia. ${ }^{10}$

\section{MMPs contribute to VSMC migration: ECM proteolysis and VSMC phenotype switch}

The VSMC are the main constituents of the tunica media of the vessels wall and significantly contribute to maintain their scaffold and tone. In the presence of mechanical force or stress and bioactive peptides $^{3,} 12$ the VSMC may switch from contractile (differentiated) to synthetic (dedifferentiated) phenotype which migrate, proliferate and produce new ECM, thus contributing to hypertension and its chronic vascular remodeling. In fact, VSMC exposed to cyclic stretch in vitro displayed more elongated morphology and a significant proliferation capacity.

For VSMC migration and proliferation, breakdown of their ECM and basement membrane is necessary, which is followed by the switch of VSMC from contractile to synthetic phenotype. MMPs degrade type IV collagen in the basement membrane of VSMC and many ECM and non-ECM components, thus allowing cell migration and ECM re-synthesize. ${ }^{13}$ In fact, cultured VSMC transfected with small inhibitory MMP-2 RNA or incubated with a MMP-2 antibody inhibited VSMC migration and their capacity to invade a Matrigel barrier in vitro. ${ }^{14,}{ }^{15}$ MMPs may also contribute to VSMC migration by degrading type I collagen as the platelet derived growth factormediated VSMC migration in the presence of type I collagen cleavage products and $\alpha v \beta 3$ integrins, but not

"Corresponding Author, E-mail:castro@fmrp.usp.br. Department of Pharmacology, Faculty of Medicine, University of Sao Paulo, Av. Bandeirantes, 3900 4049-900 Ribeirao Preto, SP, Brazil. Copyright: (c) 2015 Vanessa de Almeida Belo and Michele M. Castro. This is an open-access article distributed under the terms of the Creative Commons Attribution License. 
in the presence of the native collagen. ${ }^{16} \mathrm{MMP}-2$ may also activate transforming growth factor- $\beta$ that is involved in the phenotype switch of VSMC and the vascular rigidity. ${ }^{17}$ Furthermore, in the synthetic phenotype of VSMC, some cytoskeleton and contractile proteins are down-regulated. ${ }^{3}, 18$

Deoxycorticosterone acetate (DOCA) salt rats showed reduced calponin levels in femoral arteries and VSMC proliferation. This event is controlled by many transcriptional regulatory pathways, such as the serum response factor and its cofactor myocardin. ${ }^{18}$ DOCA salt rats also showed reduced levels of myocardin throughout the media of femoral arteries and isolated VSMC. ${ }^{18}$ MMP-2 may be more abundant in the synthetic than contractile VSMC. ${ }^{19}$ Increased MMP activity is associated with reduced cytoskeleton proteins, which resulted in VSMC migration and vascular remodeling of human saphenous vein submitted to an injury by a surgery procedure. ${ }^{20}$

\section{Concluding remarks}

Increased MMPs activity induces ECM proteolysis and VSMC phenotype switch and migration, which contribute to the maladaptive vascular remodeling of hypertension. Understanding the mechanisms that underlie the VSMC phenotype switch and migration may contribute to find new strategies to treat hypertension and other cardiovascular diseases. Targeting MMPs may reduce VSMC migration and the arterial maladaptation caused by hypertension and its fatal cardiovascular events.

\section{Acknowledgements}

Our studies are funded by Fundacao de Amparo a Pesquisa do Estado de Sao Paulo (FAPESP-Brazil). VAB is a fellow of the Coordenacao de Aperfeicoamento de Pessoal de Nivel Superior (CAPES-Brazil).

\section{References}

1. Mancia, G., R. Fagard, K. Narkiewicz, J. Redon, A. Zanchetti, M. Bohm, T. Christiaens, R. Cifkova, G. De Backer, A. Dominiczak, M. Galderisi, D.E. Grobbee, T. Jaarsma, P. Kirchhof, S.E. Kjeldsen, S. Laurent, A.J. Manolis, P.M. Nilsson, L.M. Ruilope, R.E. Schmieder, P.A. Sirnes, P. Sleight, M. Viigimaa, B. Waeber, and F. Zannad. 2013 ESH/ESC Guidelines for the management of arterial hypertension: the Task Force for the management of arterial hypertension of the European Society of Hypertension (ESH) and of the European Society of Cardiology (ESC). J Hypertens, 2013. 31(7): p. 1281-357. PubMed

2. Hayashi, K. and T. Naiki. Adaptation and remodeling of vascular wall; biomechanical response to hypertension.
J Mech Behav Biomed Mater, 2009. 2(1): p. 3-19. PubMed Full Text

3. Lacolley, P., V. Regnault, A. Nicoletti, Z. Li, and J.B. Michel. The vascular smooth muscle cell in arterial pathology: a cell that can take on multiple roles. Cardiovasc Res, 2012. 95(2): p. 194-204. PubMed

4. Lee, S. and R.T. Lee. Mechanical stretch and intimal hyperplasia: the missing link? Arterioscler Thromb Vasc Biol, 2010. 30(3): p. 459-60. PubMed Full Text

5. Briet, M. and E.L. Schiffrin. Treatment of arterial remodeling in essential hypertension. Curr Hypertens Rep, 2013. 15(1): p. 3-9. PubMed Full Text

6. Castro, M.M. and J.E. Tanus-Santos. Inhibition of matrix metalloproteinases (MMPs) as a potential strategy to ameliorate hypertension-induced cardiovascular alterations. Curr Drug Targets, 2013. 14(3): p. 335-43. PubMed Full Text

7. Briones, A.M., S.M. Arribas, and M. Salaices. Role of extracellular matrix in vascular remodeling of hypertension. Curr Opin Nephrol Hypertens, 2010. 19(2): p. 187-94. PubMed Full Text

8. Chen, Q., M. Jin, F. Yang, J. Zhu, Q. Xiao, and L. Zhang. Matrix metalloproteinases: inflammatory regulators of cell behaviors in vascular formation and remodeling. Mediators Inflamm, 2013. 2013: p. 928315. PubMed Full Text

9. Lemarie, C.A., P.L. Tharaux, and S. Lehoux. Extracellular matrix alterations in hypertensive vascular remodeling. J Mol Cell Cardiol, 2010. 48(3): p. 433-9 PubMed Full Text

10. Castro, M.M., E. Rizzi, L. Figueiredo-Lopes, K. Fernandes, L.M. Bendhack, D.L. Pitol, R.F. Gerlach, and J.E. Tanus-Santos. Metalloproteinase inhibition ameliorates hypertension and prevents vascular dysfunction and remodeling in renovascular hypertensive rats. Atherosclerosis, 2008. 198(2): p. 320-31 PubMed Full Text

11. Castro, M.M., E. Rizzi, C.M. Prado, M.A. Rossi, J.E. Tanus-Santos, and R.F. Gerlach. Imbalance between matrix metalloproteinases and tissue inhibitor of metalloproteinases in hypertensive vascular remodeling. Matrix Biol, 2010. 29(3): p. 194-201 PubMed Full Text

12. Watase, M., M.A. Awolesi, J. Ricotta, and B.E. Sumpio. Effect of pressure on cultured smooth muscle cells. Life Sci, 1997. 61(10): p. 987-96 PubMed Full Text

13. Newby, A.C. Matrix metalloproteinases regulate migration, proliferation, and death of vascular smooth muscle cells by degrading matrix and non-matrix substrates. Cardiovasc Res, 2006. 69(3): p. 614-24 PubMed Full Text

14. Turner, N.A., K.T. Hall, S.G. Ball, and K.E. Porter. Selective gene silencing of either MMP-2 or MMP-9 inhibits invasion of human saphenous vein smooth muscle cells. Atherosclerosis, 2007. 193(1): p. 36-43 PubMed Full Text

15. Uzui, H., J.D. Lee, H. Shimizu, H. Tsutani, and T. Ueda. The role of protein-tyrosine phosphorylation and gelatinase production in the migration and proliferation 
of smooth muscle cells. Atherosclerosis, 2000. 149(1):

p. 51-9 PubMed Full Text

16. Stringa, E., V. Knauper, G. Murphy, and J. Gavrilovic. Collagen degradation and platelet-derived growth factor stimulate the migration of vascular smooth muscle cells. J Cell Sci, 2000. 113(Pt 11): p. 2055-64 PubMed Full $\underline{\text { Text }}$

17. Ruiz-Ortega, M., J. Rodriguez-Vita, E. Sanchez-Lopez, G. Carvajal, and J. Egido. TGF-beta signaling in vascular fibrosis. Cardiovasc Res, 2007. 74(2): p. $196-$ 206 PubMed Full Text

18. Pfisterer, L., A. Feldner, M. Hecker, and T. Korff. Hypertension impairs myocardin function: a novel mechanism facilitating arterial remodelling. Cardiovasc Res, 2012. 96(1): p. 120-9 PubMed Full Text
19. Pauly, R.R., A. Passaniti, C. Bilato, R. Monticone, L. Cheng, N. Papadopoulos, Y.A. Gluzband, L. Smith, C. Weinstein, E.G. Lakatta, and et al. Migration of cultured vascular smooth muscle cells through a basement membrane barrier requires type IV collagenase activity and is inhibited by cellular differentiation. Circ Res, 1994. 75(1): p. 41-54 PubMed Full Text

20. Johnson, J.L., G.J. van Eys, G.D. Angelini, and S.J. George. Injury induces dedifferentiation of smooth muscle cells and increased matrix-degrading metalloproteinase activity in human saphenous vein. Arterioscler Thromb Vasc Biol, 2001. 21(7): p. 1146-51 PubMed Full Text 